\title{
High Performance Liquid Chromatography Analysis of Rutin in Allium Species Collected in Bosnia and Herzegovina
}

\author{
M. Salihovića* and E. Sofićb \\ a University of Sarajevo, Faculty of Pharmacy, Zmaja od Bosne 8, \\ 71000 Sarajevo, Bosnia and Herzegovina \\ b University of Sarajevo, Faculty of Science, Zmaja od Bosne 33-35, \\ 71000 Sarajevo, Bosnia and Herzegovina
}

\begin{abstract}
Rutin is quercetin heteroside widely present in plants that exhibit many health-beneficial effects, such as strengthening the capillary walls, reducing the harmful effects of LDL cholesterol, and reducing the risk of cardiovascular diseases. Rutin was determined from three Allium species (A. cepa, A. sativum, and A. ursinum) collected in Bosnia and Herzegovina by the HPLC method associated with electrochemical detection. The analysis was performed from methanol extracts of bulb and leaf of garlic, bulb and leaf of onion, and leaves of wood garlic. Rutin was present in all of the examined samples. The highest rutin content was found in garlic leaves $\left(0.78 \pm 0.09 \mathrm{mgg}^{-1}\right)$, and the lowest in onion bulbs $\left(0.04 \pm 0.10 \mathrm{mgg}^{-1}\right)$. The contents of rutin were higher in leaf samples, suggesting that leaves of onion and garlic are recommended as a better natural source of this glycoside.
\end{abstract}

\section{Keywords}

Allium species, rutin, HPLC-ECD method

\section{Introduction}

Flavonoids as a group of phenolic compounds are found in most plants and are part of the human diet. As part of the human diet, they are absorbed from the gastrointestinal tract and excreted unchanged or as metabolites of flavonoids in urine and faeces. These compounds are potent antioxidants, free radical scavengers, and lipid peroxidation inhibitors. Many studies have shown that flavonoids have good biological activities, including antiallergenic, antiviral, and anti-inflammatory. The onion (Allium cepa L.), as one of the better sources of flavonoids in the human diet, is common. Studies have shown total quercetin content in onion to be about $350 \mathrm{mg} \mathrm{kg}^{-1}$, which is about 10 times more in comparison with other vegetables.

The contents of onions include protein, fat, minerals $(\mathrm{Na}, \mathrm{Ca}, \mathrm{P}, \mathrm{Fe}, \mathrm{K}, \mathrm{Zn})$, fibre, carbohydrates, vitamin $C$, unsaturated sulphurs, and other organic compounds like quercetin di- and triglycosides: 3,4'-O- $\beta$-D-diglucoside, $\quad 7,4^{\prime}$-O- $\beta$-D-diglucoside, 3,7-O- $\beta$-D-diglucoside, 3-O-sophoroside-7-O- $\beta$-D-glucuronide, $3,7,4^{\prime}-O-\beta$-D-triglucoside and rutin. ${ }^{1}$

Rutin, also known as rutoside, quercetin-3-rutinoside, and sophorin, is a bioflavonoid present in buckwheat, onion, garlic, and other plants. Rutin is a heteroside which upon hydrolysis gives quercetin, glucose, and rhamnose. Its structure is shown in Fig. 1. Being discovered for the first time in Ruta graveolens L., it got its name after the herbal species. This compound is widely present in plants, and exhibits many health effects upon consumption, such as

* Corresponding author: Assoc. Prof. Mirsada Salihović

Email: mirsada.salihovic@ffsa.unsa.ba strengthening capillary walls, reducing the harmful effects of LDL cholesterol, and reducing the risk of cardiovascular diseases. $^{2}$

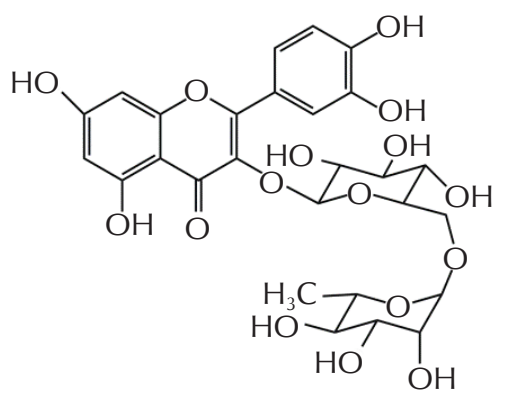

Fig. 1 - Rutin structure ${ }^{3}$

Slika 1 - Struktura rutina ${ }^{3}$

Traditionally, onions (Allium species) have been used for the treatment of asthma, antipyretic, urinary, and respiratory tract infections, as well as cardiac complaints. Many studies indicate that garlic extract has broad-spectrum antimicrobial activity against Gram-positive and Gram-negative microorganisms and potent antifungal activity. ${ }^{4}$

Onion (Allium cepa L.) is a biennial herbaceous plant of the family Alliaceae. It is related to garlic, leek, and chive, and is used in cooking and medicine. The onion has a spherical inflorescence, greenish-white flowers on one or several stems without leaves. ${ }^{5}$ The leaf basis swells to form the underground edible bulb..$^{6,7}$ Onions prevent microbial 
proliferation, may even show antibacterial effects, and are a good source of flavonoids. ${ }^{8-10}$

Garlic (Allium sativum L.) is a bulbous plant and another member of the family Alliaceae. Acknowledged as a natural antiseptic and antibiotic, garlic has been widely used in traditional medicine especially in China, India, and Southern Europe. Garlic has strong antioxidant properties that originate from phenolic compounds including flavonoids. ${ }^{11}$

Onions are an important source of phenolic compounds that imply health benefits for consumers. However, garlic is known to be an important source of organosulphur compounds. The antioxidant activity in garlic cultivars is more related to organosulphur content than phenolic content. ${ }^{12}$ Its essential oil contains allin, a compound that decomposes to allicin, which contributes to the specific smell of garlic, degrades fats, and shows antibiotic activity. ${ }^{8}$

Wood garlic, ramsons or bear leek (Allium ursinum L.) is a perennial herbaceous plant, $20-25 \mathrm{~cm}$ long, which throws up a flowering stem with a white to transparent cover. The leaves are flat and oblong. All parts of the plant are edible. It can be used to lower high blood pressure, while the other beneficial health effects are similar to those of garlic. Inexperienced pickers often do not distinguish wood garlic from poisonous plants such as crocus, lily of the valley, and hellebore. None of these plants has the specific smell of garlic, which is a useful characteristic. ${ }^{6-7}$ Because of their phytoconstituents, Allium species exhibit considerable antioxidant properties and could modulate the detoxification systems. ${ }^{9}$

The aim of this study was to determine rutin content in different species of onions by the HPLC-ECD method. The analysed onion species were: Allium sativum L., Allium cepa L., Allium ursinum L., grown in Bosnia and Herzegovina.

\section{Experimental}

\subsection{Herbal material (onion samples)}

The samples of onions were collected at the location of "Svrake", Sarajevo, Bosnia and Herzegovina. Svrake is one of eight local communities of the municipality of Vogošća that belongs to the Sarajevo Canton. In the Vogošća area, there is a sub-mountainous, moderately continental type of climate, with a favourable geographical position, climatic conditions, abundance of water, fertility of land and forest resources. Most of the population of Svrake settlement are engaged in agriculture. Some of the products are marketed.

Samples collected: parts of onion (bulbs and leaves), garlic (bulbs and leaves), and wood garlic (leaves) were stored at $-20{ }^{\circ} \mathrm{C}$ until preparation of samples and analysis.

\subsection{Chemicals}

The standard of rutin was obtained from Sigma (Germany). Methanol of HPLC analytical grade was purchased from
Merck (Germany). Acetonitrile and glacial acetic acid were of analytical grade and purchased from Panreac (Spain).

\subsection{Preparation of onion extracts}

A weighed amount of $1.0 \mathrm{~g}$ of fresh bulbs and leaves of onion and garlic, and roots of wood garlic was macerated in a mortar and pestle with $9 \mathrm{ml}$ methanol added. After $30 \mathrm{~min}$ of extraction with magnetic stirring at room temperature, the extracts were obtained by filtering through gauze. Additionally, the extracts were centrifuged for $20 \mathrm{~min}$, at $15000 \mathrm{rpm}$ and at $4{ }^{\circ} \mathrm{C}$ (Microcentrifuge, Hettich; Micro $22 \mathrm{R})$. The supernatants were evaporated to dryness, and stored at $-20{ }^{\circ} \mathrm{C}$ until analysis. Prior to analysis by the HPLC system, the dry sample extract was weighed and methanol added to prepare a concentration of $1 \mathrm{mg} \mathrm{ml}^{-1}$. All three extracts were prepared in parallel the same way.

The content of methanolic extract per $1 \mathrm{~g}$ fresh sample of Allium species is listed in Table 1.

Table 1 - Content of extract per $1 \mathrm{~g}$ fresh sample of Allium species Tablica 1 - Udio ekstrakta svježih uzoraka vrsta Alliuma

\begin{tabular}{c|c}
\hline Sample & Content $\left(\mathrm{mgg}^{-1}\right) \pm \mathrm{SD}$ \\
\hline garlic leaves & $39.2 \pm 2.2$ \\
\hline garlic bulbs & $33.0 \pm 1.65$ \\
\hline onion leaves & $46.9 \pm 1.36$ \\
\hline onion bulbs & $37.6 \pm 1.90$ \\
\hline wood garlic leaves & $58.9 \pm 0.96$ \\
\hline
\end{tabular}

Results are expressed as mean \pm standard deviations (SD) of three measurements

\subsection{Chromatographic conditions}

HPLC, Shimadzu LCSOL SINGLE-LC EN, Made in Kyoto, Japan; Detector: ECD, BAS Liquid Chromatography CC-5E, LC-4C; Pump: LC-20AT; Degasser: DGU-20A3; Oven: CTO-10Asvp; Working Electrode: Glassy carbon; model MF-1000; BASS; Reference electrode: $\mathrm{Ag} / \mathrm{AgCl}$; model MW-2030; BASS; Columns: ODS Hypersil 5 um $250 \times 4.6 \mathrm{~mm}$, Phenomene (the column was thermostated at $22{ }^{\circ} \mathrm{C}$ during the analysis); Isocratic elution, mobile phase: methanol-acetonitrile-water-acetic acid (volume

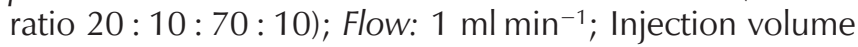
was $20 \mu \mathrm{l}$; Run time: $40 \mathrm{~min}$; Potential: $+0.84 \mathrm{~V}$.

\subsection{Identification and quantitative determination of rutin}

The identification and quantitation of rutin in onion samples after HPLC-ED analysis were done using a LabSolution program of Shimadzu (Kyoto, Japan). ${ }^{13,14}$ Rutin in the analysed samples of onion was identified by comparison of retention times with retention times of rutin's standard. The retention times of rutin in standard solution was $15.317 \pm 0.16 \mathrm{~min}$., and in onion samples 
$15.380 \pm 0.20 \mathrm{~min}$. The concentrations of rutin in onion samples were determined based on the calibration curve of a standard solution of rutin, shown in Fig. 2. Firstly, the standard stock solution of rutin was prepared in methanol, at a concentration of $1 \mathrm{mg} \mathrm{ml}^{-1}$. From the stock solution were then prepared standard solutions of concentrations: $0.1,0.2$, and $0.5 \mathrm{mg} \mathrm{ml}^{-1}$, which were used in this study.

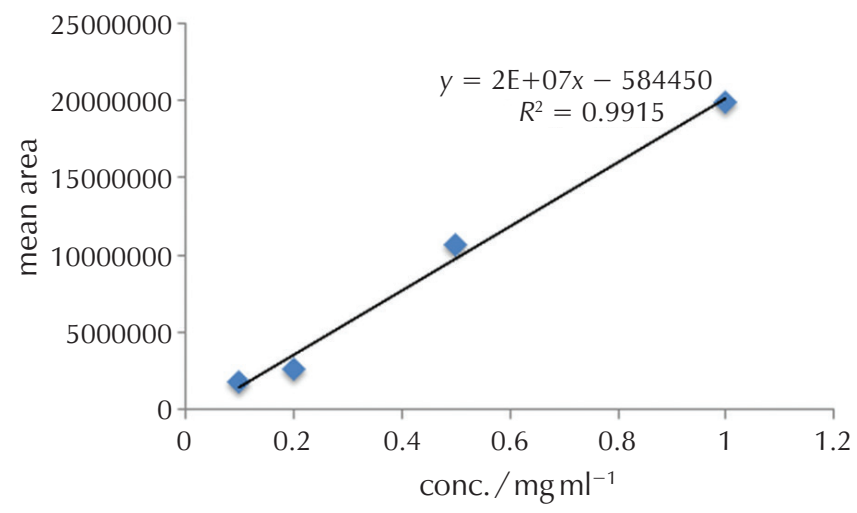

Fig. 2 - Calibration curve of standard rutin solutions Slika 2 - Kalibracijska krivulja standardnih otopina rutina

\section{Results and discussion}

The concentrations of rutin in samples were determined with the HPLC-ED method. The standard linear calibration curve was run to obtain the linear range of sample analysis.

(a)
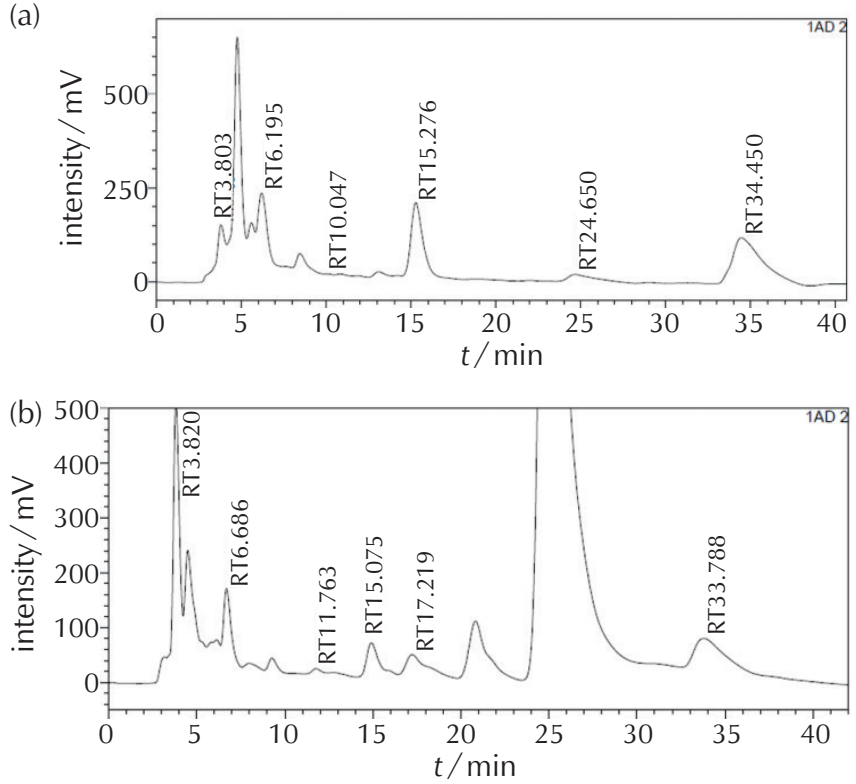

Fig. 3 - HPLC chromatograms of the methanolic extracts of garlic leaves (a) (rutin - $15.276 \mathrm{~min}$ ), and garlic bulbs (b) (rutin - $15.075 \mathrm{~min}$ )

Slika 3 - HPLC kromatogrami metanolnih ekstrakata lišća češnjaka (a) (rutina - 15,276 min) i lukovice češnjaka (b) (rutina $-15,075 \mathrm{~min}$ )
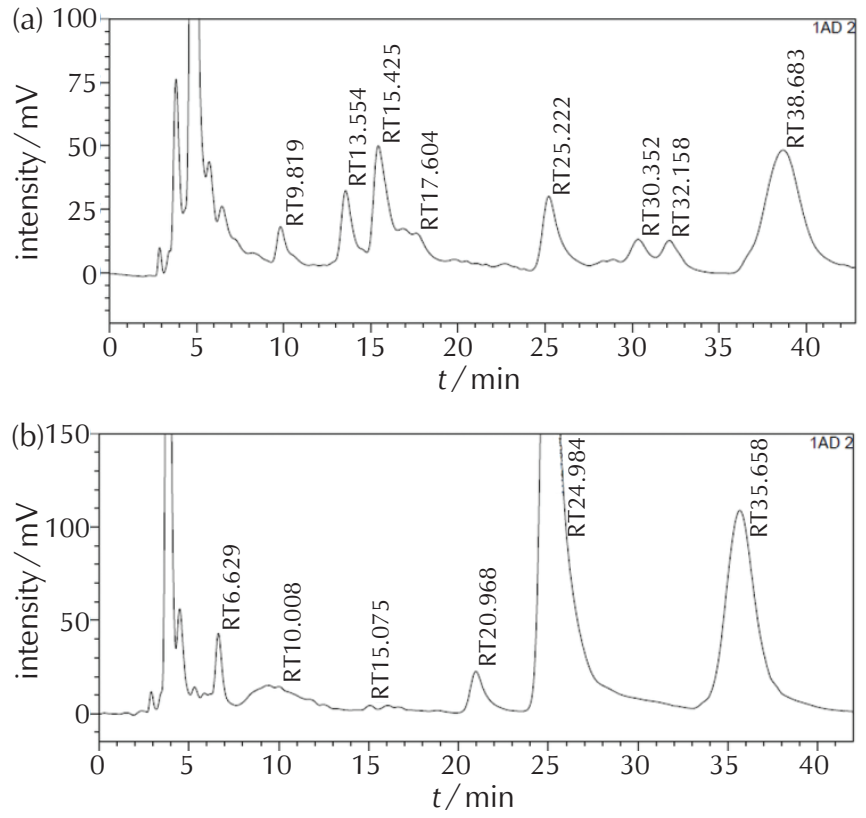

Fig. 4 - HPLC chromatograms of the methanolic extracts of onion leaves (a) (rutin - $15.426 \mathrm{~min})$, and onion bulbs (b) (rutin - $15.702 \mathrm{~min}$ )

Slika 4 - HPLC kromatogram metanolnih ekstrakata lišća crvenog luka (a) (rutina - 15,426 min) i (b) lukovice crvenog luka (b) (rutina $-15,702 \mathrm{~min}$ )

The correlation factor for rutin was with accepted value $=(0.9915)$, and the standard calibration curve was linear over the range $\left(0.1-1.0 \mathrm{mg} \mathrm{ml}^{-1}\right)$. The limit of detection (LOD) and limit of quantification (LOQ) were calculated from equations. ${ }^{15}$ LOD for rutin was $0.0111 \mathrm{mg} \mathrm{ml}^{-1}$ and LOQ was $0.037 \mathrm{mg} \mathrm{m}^{-1}$. Representative HPLC chromatograms of the leaves and bulbs of garlic (Allium sativum L.) are presented in Fig. 3; leaves and bulbs of onion (Allium сера L.) in Fig. 4, and in the wood garlic (Allium ursinum L.) leaves in Fig. 5.

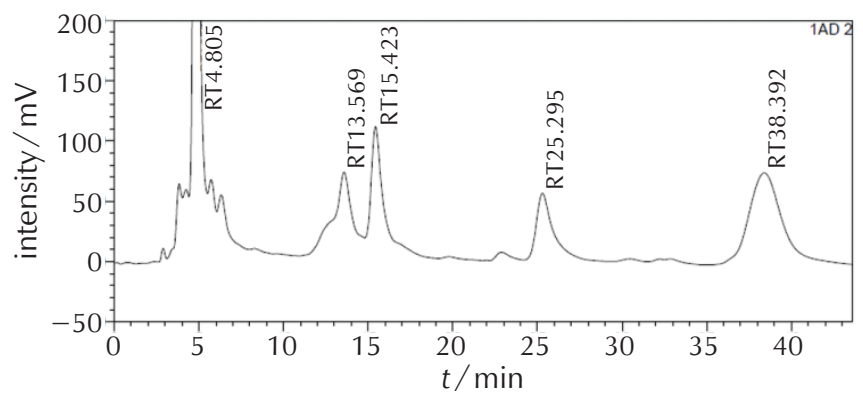

Fig. 5 - HPLC chromatogram of the methanolic extract of wood garlic leaves (rutin - $15.423 \mathrm{~min}$ )

Slika 5 - HPLC kromatogram metanolnog ekstrakata lišća medvjeđeg luka (rutina - 15,423 min)

One can notice that retention times of rutin among all samples are different. Since the retention time is the only iden- 
Table 2 - Content of rutin in Allium species

Tablica 2 - Udio rutina u vrstama Alliuma

\begin{tabular}{c|c|c|c|c|c}
\hline & Garlic leaves & Garlic bulbs & Onion leaves & Onion bulbs & Wood garlic leaves \\
\hline rutin $/ \mathrm{mgg}^{-1}$ & $0.78 \pm 0.09$ & $0.33 \pm 0.13$ & $0.19 \pm 0.21$ & $0.04 \pm 0.10$ & $0.46 \pm 0.17$ \\
\hline
\end{tabular}

Results are expressed as mean \pm standard deviations (SD) of three determinations.

tification parameter after HPLC analysis of one sample, that sample was mixed with the standard and re-analysed by HPLC. Thereafter, the identification peak had a larger surface area at the same retention time. This was an indication that retention times, although different, fitted those of rutin. Rutin was identified in all samples of Allium species. The obtained concentrations are shown in Table 2.

Quantitative differences of rutin were found between the leaves and bulbs. The highest rutin concentration was found in the garlic leaves $\left(0.78 \pm 0.09 \mathrm{mgg}^{-1}\right)$, whereas the lowest rutin concentration was found in the onion bulbs $\left(0.04 \pm 0.10 \mathrm{mg} \mathrm{g}^{-1}\right)$. One of the studies found that in an immature garlic plant, the content of quercetin equivalent was significantly higher $(6.99 \mathrm{lg} \mathrm{QE} / \mathrm{g}$ ) than in mature plant bulbs (5.78 and 4.16 lg QE/g). ${ }^{16}$ Rutin has been previously identified in onion leaves. ${ }^{17}$ The content of rutin in Spanish white onions (varieties white onion, and Calcot de Vall) extracts ranged from $0.56 \pm 0.06$ to $11.5 \pm 0.93 \mathrm{mg}$ rutin /g dry weight. ${ }^{18}$ Earlier studies ${ }^{14,19-22}$ and our investigation showed that leaves of the Allium species contain more rutin than other parts of the plant.

\section{Conclusions}

We determined the contents of rutin in Allium sativum L., Allium cepa L., Allium ursinum L. collected in Bosnia and Herzegovina. The contents of rutin were obtained using the HPLC-ED method. It was observed that leaves of onion and garlic contained higher concentration values in comparison to bulbs, while leaves of wood onion had a high content of rutin. Our study has shown that rutin content of leaves was higher compared that in the bulbs of Allium species. Rutin has many beneficial health effects, such as strengthening capillary walls, reducing harmful effects of LDL cholesterol, and reducing the risk of cardiovascular diseases. Because our results have shown that Allium species contain more rutin, and due to rutin's aforementioned health benefits, they are recommended as a better natural source of this glycoside.

\section{References Literatura}

1. J. Lachman, D. Pronek, A. Hejtmánková, J. Dudjak, V. Pivec, $K$. Faitová, Total polyphenol and main flavonoid antioxidants in different onion (Allium cepa L.) varieties, Hort. Sci. 30 (2011) 142-147, doi: https://doi.org/10.17221/3876-hortsci.

2. N. Lucci, P. Mazzafera, Rutin synthase in fava d'anta: Purification and influence of stressors, Can. J. Plant. Sci. 89 (2009)
895-902, doi: https://doi.org/10.4141/cjps09001.

3. A. E. Al-Snafi, Pharmacological effects of Allium species grown in Iraq. An overview, J. Pharm. Hea. Care Res. 1 (2013) 132-147.

4. J. Y. Lallemand, M. Duteil, ${ }^{13} \mathrm{C} \mathrm{nmr}$ spectra of quercetin and rutin, Org. Magne. Reson. 9 (1977) 179-180, doi: https:// doi.org/10.1002/mrc.1270090317.

5. M. G. Jones, Biosynthesis of the flavor precursors of onion and garlic, J. Exp. Bot. 55 (2004) 1903-1918, doi: https:// doi.org/10.1093/jxb/erh138.

6. I. Dini, G. C. Tenore, A. Dini, S-Alkenyl Cysteine Sulfoxide and Its Antioxidant Properties from Allium cepa var. tropeana (Red Onion) Seeds, J. Nat. Prod. 71 (2008) 2036-2037, doi: https://doi.org/10.1021/np800237w.

7. J.-H. Kwak, J. M. Seo, N.-H. Kim, M. V. Arasu. S. Kim, M. K. Yoon, S.-J. Kim, Variation of quercetin glycoside derivatives in three onion (Allium cepa L.) varieties, Saudi. J. Biol. Sci. 24 (2017) 1387-1391, doi: https://doi.org/10.1016/j. sjbs.2016.05.014.

8. G. Q. Shi, J. Yang, J. Liu, S. N. Liu, H. X. Song, W. E. Zhao, Y. Q. $\mathrm{Liu}$, Isolation of flavonoids from onion skin and their effects on K562 cell viability, Bangladesh J. Pharmacol. 11 (2016) 18-25, doi: https://doi.org/10.3329/bjp.v11i0.26419.

9. G. J. H. Grubben, O. A. Denton, Plant resources of tropical Africa 2. Vegetables. PROTA Foundation Publ., Netherlands, 2004, pp. 667-685.

10. D. Zohary, M. Hopf, Domestication of plants in the Old World: the origin and spread of cultivated plants in West Asia, Europe and the Nile Valley. Oxford University Press Pub., UK, 2000, pp. 316-345.

11. E. Azzini, A. Durazzo, M. S. Foddai, O. Temperini, E. Venneria, S. Valentini, G. Maiani, Phytochemicals content in Italian garlic bulb (Allium sativum L.) varieties, J. Food Res. 3 (2014) 26, doi: https://doi.org/10.5539/jfr.v3n4p26.

12. V. C. Soto, R. E. González, M. M. Sance, C. R. Galmarini, Organosulfur and phenolic content of garlic (Allium sativum L.) and onion (Allium cepa L.) and its relationship with antioxidant activity, in: VII International Symposium on Edible Alliaceae 1143 (2016) 277-290, doi: https://doi. org/10.17660/actahortic.2016.1143.39.

13. V. Lanzotti, The analysis of onion and garlic, J. Chromatogr. A 1112 (2006) 3-22, doi: https://doi.org/10.1016/j.chroma.2005.12.016.

14. E. Sofic, A. Copra-Janicijevic, M. Salihovic, I. Tahirovic, G. Kroyer, Screening of medicinal plant extracts for quercetin-3-rutinoside (rutin) in Bosnia and Herzegovina, Med. Plants. 2 (2010) 97-102, doi: https://doi.org/10.5958 j.0975-4261.2.2.015

15. S. Yilmaz, Z. Bas, M. Sadikoglu, S. Yagmur, G. Saglikoglu, Sensitive Voltammetric Determination of Paracetamol on Poly (4-Aminobenzene Sulfonic Acid) Modified Glassy Carbon Electrode, Intern. J. Electroche. Sci. 11 (2016) 6244-6255, doi: https://doi.org/10.20964/2016.07.74.

16. B. Bozin, N. Mimica-Dukic, I. Samojlik, A. Goran, R. Igic, Phenolics as antioxidants in garlic (Allium sativum L., Al- 
liaceae), Food Chem. 111 (2008) 925-929, doi: https://doi. org/10.1016/j.foodchem.2008.04.071.

17. M. Parvu, A. Toiu, L. Vlase, E. Parvu, Determination of some polyphenolic compounds from Allium species by HPLC-UVMS, Nat. Prod. Res. 24 (2010) 1318-1324, doi: https://doi. org/10.1080/14786410903309484.

18. J. Santas, R. Carbo, M. H. Gordon, M. P. Almajano, Comparison of the antioxidant activity of two Spanish onion varieties, Food Chem. 107 (2008) 1210-1216, doi: https://doi. org/10.1016/j.foodchem.2007.09.056.

19. M. Marotti, R. Piccaglia, Characterization of flavonoids in different cultivars of onion (Allium cepa L.),
J. Food Sci. 67 (2002) 1229-1232, doi: https://doi. org/10.1111/j.1365-2621.2002.tb09482.x.

20. S. J. Kim, G. H. Kim, Quantification of quercetin in different parts of onion and its DPPH radical scavenging and antibacterial activity, Food Sci. Biotechnol. 15 (2006) 39-43.

21. L. H. Yao, Y. M. Jiang, J. Shi, F. A. Tomas-Barberan, N. Datta, R. Singanusong, S. S. Chen, Flavonoids in food and their health benefits, Plant. Food Hum. Nutr. 59 (2004) 113-122, doi: https://doi.org/10.1007/s11130-004-0049-7.

22. S. Sellappan, C. C. Akoh, Flavonoids and antioxidant capacity of Georgia-grown Vidalia onions, J. Agric. Food Chem. 50 (2002) 5338-5342, doi: https://doi.org/10.1021/jf020333a.

\section{SAŽETAK}

\section{Analiza rutina tekućinskom kromatografijom visoke učinkovitosti u vrstama Allium sakupljenim u Bosni i Hercegovini \\ Mirsada Salihovića $a^{*}$ i Emin Sofićb}

Rutin je heterozid kvarcetin široko rasprostranjen u biljkama i pokazuje brojne pozitivne učinke na zdravlje, poput jačanja stijenki kapilara, smanjenja štetnih učinaka LDL kolesterola i smanjenja rizika od bolesti krvožilnog sustava. Udio rutina određen je u tri vrste roda Allium (A. cepa, A. sativum i $A$. ursinum) koje rastu u Bosni i Hercegovini primjenom tekućinske kromatografije visoke učinkovitosti s elektrokemijskom detekcijom (HPLC-ECD). Analiza je provedena u metanolnim ekstraktima lukovice i lista češnjaka, lukovice i lista crvenog luka, lista medvjeđeg luka. Rutin je određen u svim analiziranim uzorcima vrste Allium. Najveći sadržaj rutina određen je u listovima češnjaka $\left(0.78 \pm 0.09 \mathrm{mg} \mathrm{g}^{-1}\right)$, a najmanji u crvenom luku $\left(0.04 \pm 0.10 \mathrm{mg} \mathrm{g}^{-1}\right)$. Udjeli rutina bili su veći u uzorcima lišća, što sugerira da se listovi luka i češnjaka preporučuju kao bolji prirodni izvor ovog glikozida.

\section{Ključne riječi}

Vrste Allium, rutin, metoda HPLC-ECD

a Farmaceutski fakultet

Univerzitet u Sarajevu

Zmaja od Bosne 8, 71000 Sarajevo

Bosna i Hercegovina

b Prirodno-matematički fakultet

Univerzitet u Sarajevu

Zmaja od Bosne 8, 71000 Sarajevo

Bosna i Hercegovina
Prethodno priopćenje Prispjelo 22. siječnja 2020. Prihvaćeno 22. travnja 2020. 